\title{
A Monoclonal Antibody to Human Platelet Glycoprotein Illa Detects a Related Protein in Cultured Human Endothelial Cells
}

\author{
Perumal Thiagarajan, Sandor S. Shapiro, Elliot Levine, Luigi DeMarco, and Atilla Yalcin \\ Cardeza Foundation for Hematologic Research, Department of Medicine, Jefferson Medical College, Philadelphia, Pennsylvania 19107; \\ and The Wistar Institute, Philadelphia, Pennsylvania 19104
}

\begin{abstract}
We have previously described a series of monoclonal antibodies against platelet membrane glycoproteins. Two of the antibodies, B59.2 and B2.12, recognize the glycoprotein IIb-IIIa complex. These two antibodies react specifically with glycoprotein (GP) IIIa, as shown by immunoblotting of sodium dodecyl sulfatepolyacrylamide gels of solubilized platelet membranes. Monoclonal B2.12, but not B59.2, binds to cultured human endothelial cells obtained from umbilical vein, internal iliac artery, and inferior vena cava. At saturation $\sim \mathbf{1 0 0 , 0 0 0}$ binding sites were detected per human umbilical vein endothelial cell. When solubilized radioiodinated cells were chromatographed on a column of agarose-bound B2.12, a single radiolabeled protein was obtained whose apparent molecular weight is slightly larger than that of platelet GP IIIa. This protein incorporated [ ${ }^{35}$ S]methionine when endothelial cells were labeled metabolically. These results demonstrate that human endothelial cell membranes synthesize a protein immunologically related to platelet GP IIIa.
\end{abstract}

\section{Introduction}

Glycoproteins IIb (GP IIb) ${ }^{1}$ and IIIa (GP IIIa) form a major heterodimeric complex in platelet membranes that is involved in fibrinogen binding and platelet aggregation (1-8). In addition, the GP IIb-IIIa complex appears to be a site for the binding of Factor VIII and fibronectin to thrombin-stimulated platelets (9-11) and may also provide a site for the binding of the cytoskeletal protein network to the platelet membrane (12). Absence or decreased amount of the platelet GP IIb-IIIa complex characterizes the inherited bleeding disorder thrombasthenia, and platelets from thrombasthenic patients show decreased fibrinogen binding and impaired aggregation (1-8, 12, 13).

Dr. P. Thiagarajan is an established investigator of the American Heart Association. Part of this work was presented at the National Meeting of the American Society for Clinical Investigation, 30 April 1983, and published in abstract form in 1983. Clin. Res. 31:485.

Address reprint requests to Dr. Thiagarajan.

Received for publication 13 February 1984 and in revised form 16 November 1984.

1. Abbreviations used in this paper: ECGF, endothelial cell growth factor; GP IIb and GP IIIa, glycoproteins IIb and IIIa; GP IIb-IIIa complex, glycoprotein IIb-IIIa complex; PMSF, phenylmethylsulfonylfluoride.

J. Clin. Invest.

(c) The American Society for Clinical Investigation, Inc.

0021-9738/85/03/896/06 $\$ 1.00$

Volume 75, March 1985, 896-901
Platelets and their parent cells, the megakaryocytes, appear to share several characteristics with vascular endothelial cells. Both synthesize Factor-VIII-related antigen $(14,15)$; in addition, endothelial cells have been shown to synthesize fibrinectin (16-18), thrombospondin $(19,20)$, a mitogenic factor for smooth muscle (21), and Factor V (22), all of which are also present in platelets. Furthermore, both cell types have binding sites for thrombin (23-25) and Factor Xa $(26,27)$ and provide an effective surface for prothrombin activation $(26,27)$. We used monoclonal antibodies against human platelet GP IIIa to show the presence of a platelet GP-IIIa-related protein in human endothelial cell membranes.

\section{Methods}

Silicone oils (methylsilicone DC 200 and diphenylsilicone DC 550) were purchased from William F. Nye, Inc., Fairhaven, MA. Nonidet P40 (NP40) was purchased from Particle Data, Inc., Elmhurst, IL. $\mathrm{Na}^{125} \mathrm{I}$ was obtained from Cambridge Nuclear Corp., Billerica, MA. Protein A Sepharose was obtained from Pharmacia Fine Chemicals, Div. of Pharmacia Inc., Piscataway, NJ. Sodium dodecyl sulfate (SDS) and iodogen were obtained from Pierce Chemical Co., Rockford, IL. Acrylamide, molecular weight standards for electrophoresis, Tween 20, Affigel 10, and Bio-Gel A-5M were purchased from Bio-Rad Laboratories, Richmond, CA. Bovine albumin (fraction V), heparin (sodium salt, grade I from porcine intestinal mucosa, $168 \mathrm{U} / \mathrm{mg}$ ), leupeptin, benzamidine, and phenylmethylsulfonylfluoride (PMSF) were obtained from Sigma Chemical Co., St. Louis, MO. Phosphorylase B (methyl${ }^{14} \mathrm{C}$ ) was obtained from New England Nuclear, Boston, MA. Standard laboratory chemicals were purchased from Fisher Scientific Co., Allied Corp., Pittsburgh, PA. Tissue culture medium, bovine fetal serum, gelatin, and trypsin were obtained from Gibco Laboratories, Grand Island, NY. Endothelial cell growth factor (ECGF) was prepared as described before (28). Platelets were obtained from two patients with thrombasthenia (N.M. and M.M.) who have been described previously (29).

Monoclonal antibodies. The procedures for fusion, screening of hybrids, cloning, production of ascites, Ig purification, and class and subclass characterization have been reported in detail elsewhere (30). Monoclonal B2.12 is an $\mathrm{IgG}_{1}$, and monoclonal B59.2 is an $\mathrm{IgG}_{2 \mathrm{a}}$; in the presence of protein A Sepharose, both monoclonals precipitate the GP IIb-IIIa complex from Triton X-100-solubilized platelet membranes (30). Neither antibody reacts with monocytes, polymorphonuclear leukocytes, or lymphocytes in peripheral blood when analyzed in a flow cytofluorimeter (cytofluorograph system 50H; Ortho Diagnostic Systems Inc., Westwood, MA) with indirect immunofluorescence using a fluorescein-labeled goat $\mathrm{F}\left(\mathrm{ab}^{\prime}\right)_{2}$ anti-mouse $\mathrm{Ig}$, as described previously (30). Furthermore, neither antibody reacts with myeloid cell lines (KG-1, HL60, ML3), B cell lines (Karpas 120, Raji, Daudi, LIK, SB, and 8866 ), or $T$ cell lines (HSB2, Karpas 45 , Jurkat, Molt 4 , and CEM) when tested in an indirect radioimmunobinding assay (30). Two monoclonal antibody controls were used: $\mathrm{B} 33.1$, an $\mathrm{IgG}_{2 \mathrm{a}}$ directed against the HLA-Dr common determinant, and B66.7, an $\mathrm{IgG}_{1}$ antipan T cell (gifts of Dr. G. Trinchieri and Dr. B. Perussia, The Wistar Institute, Philadelphia, PA). The antibodies were purified from ascitis fluid by protein A Sepharose column chromatography, as described 
previously (30). $F\left(a b^{\prime}\right)_{2}$ fragments were prepared by pepsin digestion followed by removal of intact IgG by protein A Sepharose as described previously (31). The purified antibodies were labeled by the chloramine T method (32) at $1,500-4,000 \mathrm{Ci} / \mathrm{mM}$ sp act $(2,000-5,000 \mathrm{cpm} / \mathrm{ng})$.

Preparation of platelets. Blood from normal volunteers and from the two patients with thrombasthenia was collected into 1:9 vol of $3.8 \%$ trisodium citrate. Platelet-rich plasma was obtained by centrifugation at $150 \mathrm{~g}$ for $15 \mathrm{~min}$ at room temperature. It was then centrifuged at room temperature for $10 \mathrm{~min}$ at $2,000 \mathrm{~g}$. The platelet pellet was resuspended in a washing buffer consisting of $0.15 \mathrm{M} \mathrm{NaCl}, 0.02 \mathrm{M}$ Tris, $2 \mathrm{mM}$ EDTA, $5 \mathrm{mM}$ dextrose, and $1 \mathrm{mg} / \mathrm{ml}$ albumin, $\mathrm{pH} 7.5$, and washed three times in this buffer by sedimentation. For binding studies, the platelet button was suspended in $\mathrm{pH} 7.5$ buffer containing $0.15 \mathrm{M} \mathrm{NaCl}, 0.02 \mathrm{M}$ Tris, $5 \mathrm{mM}$ dextrose, and $1 \mathrm{mg} / \mathrm{ml}$ albumin, pH 7.5, but no EDTA.

Preparation of endothelial cells. Human endothelial cells were grown in T-75 tissue culture flasks (Corning Glass Works, Corning Science Products, Corning, NY) in medium 199 containing $20 \mu \mathrm{g} / \mathrm{ml}$ ECGF, $16 \mathrm{U} / \mathrm{ml}$ heparin, and $20 \%$ fetal calf serum, as described previously (33). These cells stain positively for Factor VIII antigen and exhibit angiotensin-converting enzyme activity (33). At confluence the tissue culture supernatant was aspirated, and the monolayers were washed twice with balanced salt solution. The monolayers were detached by exposure for $30-60 \mathrm{~s}$ to a solution containing $0.25 \%$ trypsin (wt/ vol) and $0.09 \%$ EDTA in normal saline. The detached cells were incubated with tissue culture medium containing $20 \%$ fetal calf serum to neutralize trypsin and centrifuged at $150 \mathrm{~g}$. The cell suspensions were washed twice in the washing buffer described above. For binding studies the cells were suspended in the same washing buffer, but without EDTA. In some experiments the cells were detached nonenzymatically by incubation at $37^{\circ} \mathrm{C}$ for $30 \mathrm{~min}$ in phosphate-buffered saline $(0.15 \mathrm{M} \mathrm{NaCl}, 0.02 \mathrm{M}$ phosphate, $\mathrm{pH} 7.5)$ containing $5 \mathrm{mM}$ EDTA.

Two cloned endothelial cell strains, derived from human umbilical vein (HUVE-12M) and human aorta (HAAE-1F), were used. The cloned cells had undergone 30 cumulative population doublings in culture at the time of these studies. In addition, cultured human endothelial cell lines derived from internal iliac artery (HIAE-25) and inferior vena cava (HIYCE-17) were used in electrophoretic studies. These cells had undergone 3 and 10 cumulative population doublings, respectively, at the time of the studies. The cloned endothelial cell strains were used in binding studies (HUVE-12M), in surface labeling with ${ }^{125}$ I (HUVE-12M), and in metabolic labeling with $\left[{ }^{35}\right.$ S $]$ methionine (HAAE-1F). All the cell lines were used in immunoblotting studies. Human aortic smooth muscle cells were used as negative controls in immunoblotting studies.

Binding studies. Suspensions of $200 \mu$ platelets $\left(3 \times 10^{8} / \mathrm{ml}\right)$ or $200 \mu \mathrm{l} \mathrm{HUVE}$ cells $\left(10^{6} / \mathrm{ml}\right)$ were incubated for periods of $2-120 \mathrm{~min}$ with each monoclonal antibody at room temperature or at $4^{\circ} \mathrm{C}$ in 500- $\mu$ l Eppendorf tubes. After incubation the tube contents were layered onto silicone oil in micro-Eppendorf centrifuge tubes (Fisher Scientific Co., Allied Corp.) and spun at $10,000 \mathrm{~g}$ for $2 \mathrm{~min}$ at room temperature in an Eppendorf model 3200 centrifuge (Fisher Scientific Co., Allied Corp.). The pellet and supernatant were counted separately in an Isodyne gamma counter (model 1185; G. D. Searle \& Co., Chicago, IL). For dose response curves, various concentrations (0.01$10 \mu \mathrm{g} / \mathrm{ml}$ ) of labeled antibody were incubated with endothelial cells or platelets for $10 \mathrm{~min}$. "Nonspecific" binding was measured at a 100 fold excess of unlabeled antibody and subtracted from the total bound to give "specific" binding. In addition, a monoclonal anti-T-cell antibody, B66.7, that does not react with endothelial cells, as shown by indirect radioimmunoassay and western blotting, was labeled and used as a negative control in the binding studies. Specific binding was analyzed according to the method of Scatchard, as described previously (5).

Electrophoresis and western blotting. Pellets of washed platelets or endothelial cells were suspended in a lysing buffer consisting of $1 \%$
NP40, $0.15 \mathrm{M} \mathrm{NaCl}, 0.02 \mathrm{M}$ Tris, $1 \mathrm{mM}$ PMSF, $5 \mathrm{mM}$ benzamidine, and $100 \mu \mathrm{g} / \mathrm{ml}$ leupeptin, $\mathrm{pH} 7.5$, and incubated at $4^{\circ} \mathrm{C}$ for $15 \mathrm{~min}$. The lysates were centrifuged at $10,000 \mathrm{~g}$ for $10 \mathrm{~min}$ at $4^{\circ} \mathrm{C}$ to remove cell debris and nuclei. The supernatants were subjected to SDSpolyacrylamide gel electrophoresis (SDS-PAGE), according to the method of Laemmli, with a $3 \%$ stacking gel and a $7 \%$ resolving gel (34). The resolved proteins were electrophoretically transferred to nitrocellulose paper (Schleicher \& Schuell, Inc., Keene, NH) using a buffer system of $0.075 \mathrm{M}$ glycine, $0.01 \mathrm{M}$ Tris, and $10 \%$ methanol, pH 8.3 (35). After transfer, the nitrocellulose paper was incubated for $1 \mathrm{~h}$ in $3 \%$ bovine serum albumin to block nonspecific binding, and then incubated with ${ }^{125}$ I-labeled monoclonal antibodies $\left(2 \times 10^{5} \mathrm{cpm}\right)$ for $90 \mathrm{~min}$ at room temperature. The paper was washed five times in Tris-buffered saline $(0.02 \mathrm{M}$ Tris and $0.15 \mathrm{NaCl}, \mathrm{pH} 7.5)$ containing $0.05 \%$ Tween 20 , dried, and autoradiographed at $-70^{\circ} \mathrm{C}$ for $18 \mathrm{~h}$ using Kodak X-Omat AR film and a Lightning-Plus intensifying screen (E. I. DuPont de Nemours \& Co., Inc./Sorvall Instruments Div., Newtown, CT).

Radioiodination of endothelial cells. HUVE cells, detached nonenzymatically, were washed and suspended in phosphate-buffered saline at a concentration of $2 \times 10^{6} / \mathrm{ml}$. An aliquot $(500 \mu \mathrm{l})$ of the cell suspension was radioiodinated with $2 \mathrm{mCi}$ of $\mathrm{Na}^{125}$ I by the iodogen method (36). The reaction was terminated by washing the cells three times in cold phosphate-buffered saline containing $1 \mathrm{mM}$ PMSF. After the final wash the pellet was lysed by suspension in $1 \mathrm{ml}$ of the lysing buffer for $30 \mathrm{~min}$ on ice with occasional vortexing. The lysate was centrifuged at $10,000 \mathrm{~g}$ for $10 \mathrm{~min}$ at $4^{\circ} \mathrm{C}$ in Eppendorf centrifuge, and the supernatant stored at $-70^{\circ} \mathrm{C}$.

Affinity chromatography. The monoclonal antibody B2.12 was coupled to Affigel 10 , using $55 \mathrm{mg}$ of antibody for $5 \mathrm{ml}$ of gel (37). Washed platelets $\left(1 \times 10^{11}\right)$ were disrupted by sonication in a sonicator (Branson Sonic Power Co., Danbury, CT) and centrifuged at $10,000 \mathrm{~g}$ for $1 \mathrm{~h}$ at $4^{\circ} \mathrm{C}$ (model L3-50 ultracentrifuge, Beckman Instruments, Inc., Palo Alto, CA). The membrane proteins were solubilized in the lysing buffer, "precleared" by passage through a $1 \times 4-\mathrm{cm}$ column of normal mouse IgG coupled to Affigel 10 , and then applied to the immunoaffinity column. Bound proteins were eluted with $0.05 \mathrm{M}$ diethylamine and 1\% NP40, pH 11.5, as described by Parham (38). The eluate was immediately neutralized with 1:20 vol of $1 \mathrm{M}$ Tris, $\mathrm{pH}$ 7.5 , and dialyzed at $4^{\circ} \mathrm{C}$ against lysing buffer. In some experiments solubilized platelet membranes were mixed with solubilized radiolabeled endothelial cells, and the mixture subjected to affinity chromatography.

Metabolic labeling. HAAE-IF were grown to confluence as described above and washed in methionine-free medium 199. Fresh methioninefree medium 199, containing ECGF, heparin, fetal calf serum, and $500 \mu \mathrm{Ci}\left[{ }^{35} \mathrm{~S}\right]$ methionine (Amersham Corp., Arlington Heights, IL) was added. After $24 \mathrm{~h}$ of incubation, the medium was removed, and the cells were washed and then solubilized in the lysing buffer and subjected to affinity chromatography as described above. The cells and eluate were subjected to SDS-PAGE (7\%), and proteins were identified by fluorography (18).

Polyclonal antibody against GP IIIa. The platelet GP IIb-IIIa complex was isolated by immunoaffinity chromatography, and the isolated complex was subjected to SDS-PAGE in 7\% gels. The bands representing GP IIb and GP IIIa were identified by staining for 15 min with $0.25 \%$ Coomassie blue in $50 \%$ methanol $/ 0.5 \%$ acetic acid for $2 \mathrm{~h}$. The transverse strips containing GP IIIa were cut out and chopped into pieces and eluted by agitating in $0.125 \mathrm{M}$ Tris, $0.1 \%$ SDS, and 1 mM PMSF overnight at room temperature. The eluted proteins were injected into rabbits weekly for $6 \mathrm{wk}$. Rabbit serum was heat-inactivated and absorbed with platelets from a patient with Glanzmann's thromboasthenia $\left(1 \times 10^{9}\right.$ platelets $/ \mathrm{ml}$ of serum $)$. Ouchterlony double immunodiffusion was performed in $1 \%$ agarose (Seakem ME; FMC Corp., Rockland, ME), $0.15 \mathrm{M} \mathrm{NaCl}$, and $0.02 \mathrm{M}$ Tris, $\mathrm{pH} 7.5$, containing $1 \%(\mathrm{vol} / \mathrm{vol})$ Triton $\mathrm{X}-100$. The wells contained solubilized platelets $\left(10^{8} / \mathrm{ml}\right)$, or endothelial cells $\left(10^{6} / \mathrm{ml}\right)$, or $10 \mu \mathrm{g}$ of affinity-purified platelet GP IIIa. 


\section{Results}

Binding of monoclonals to platelets. As previously described (30), monoclonal antibodies B2.12 and B59.2 bind to platelets saturably. Binding was complete within 2 min and was completely reversible in the presence of a 100 -fold excess of cold antibody. At saturation $\sim 21,000$ binding sites were detected on the platelet surface with B2.12 and B59.2. The extent of binding was the same in stimulated and unstimulated platelets and was unaffected by the presence of $5 \mathrm{mM} \mathrm{Ca}^{++}$or $5 \mathrm{mM}$ EDTA. In two patients with thrombasthenia, binding with B2.12 was $\sim 10 \%$ of normal and with B59.2 $\sim 5 \%$ of normal. The immunologic specificity of these two antibodies was further characterized by a combination of SDS-PAGE and western blotting; both B2.12 and B59.2 detected a single protein in solubilized platelet membranes with an apparent molecular weight of 95,000 (Fig. 1). When electrophoresis was performed in the presence of reducing agents, this protein showed the increase in molecular weight characteristic of GP IIIa, but samples run in this manner showed greatly reduced antigenic activity in western blots.

Binding of monoclonals to endothelial cells. When endothelial extracts were examined for reactivity against these monoclonal antibodies by SDS-PAGE and western blotting, B2.12 identified a single protein with a molecular weight similar to, but not identical with, that of platelet GP IIIa (Fig. 2). In contrast to the finding in platelets, however, monoclonal B59.2 did not react with these endothelial cell extracts. Identical results were obtained with endothelial cells detached from culture plates by enzymatic and nonenzymatic means. Neither B2.12 nor B59.2 reacted with human aortic smooth muscle cell extracts under similar conditions. As shown in Fig. 3, B2.12 bound to human umbilical vein endothelial cells saturably. Binding was complete within $2 \mathrm{~min}$ (not shown). At saturation a single class of binding sites $(\sim 100,000$ per endothelial cell) was detected, with an affinity constant of 2.4 $\times 10^{-8} \mathrm{M}$, similar to that found for platelets. In agreement with immunoblotting slides, monoclonal B59.2 did not bind to umbilical vein endothelial cells significantly more than the control-labeled monoclonal antibody B66.7.

Reactivity of platelets and endothelial cells against polyclonal platelet GP IIIa antiserum. A polyclonal rabbit antiserum against platelet GP IIIa reacted with Triton X-100-solubilized

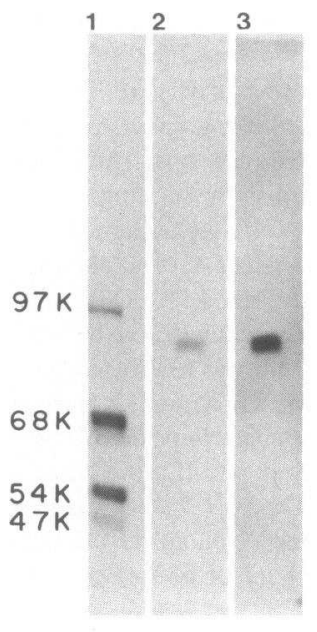

STDS B2.12 B59.2
Figure 1. Reactivity of monoclonals washed platelets solubilized in $1 \%$ Triton were run on SDS-PAGE (7\%), transferred to nitrocellulose paper, incubated with ${ }^{125}$ I-labeled antibodies, washed, and autoradiographed. Lane 1 , radioactive molecular weight standards (phosphorylase B and reduced fibrinogen). Lane 2, monoclonal B2.12. Lane 3, monoclonal B59.2. $\mathrm{K}, \times 1,000 \mathrm{~mol}$ wt. B2.12 and B59.2 with platelets. Pellets of

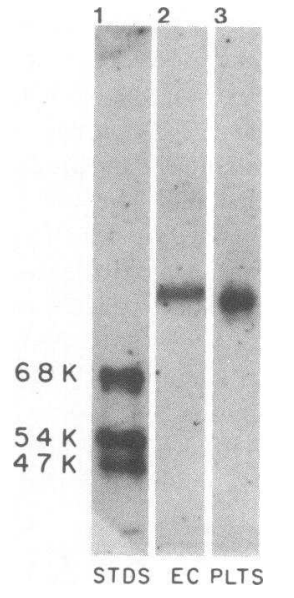

Figure 2. Reactivity of B2.12 with platelets and endothelial cells. Pellets of washed platelets and endothelial cells solubilized in 1\% Triton were run on SDS-PAGE, transferred to nitrocellulose paper, incubated with ${ }^{125} \mathrm{I}$ labeled B2.12, washed, and autoradiographed. Lane 1, radioactive molecular weight standards (reduced fibrinogen). Lane 2, endothelial cells. Lane 3, platelets. K, $\times 1,000 \mathrm{~mol}$ wt.

endothelial cells as well as with solubilized platelets, giving a line of identity (Fig. 4).

Affinity chromatography. We attempted to purify the endothelial cell GP-IIIa-related protein by affinity chromatography on a B2.12 Affigel column, a technique similar to the one we employed for platelets. However, when endothelial cells were used we had great difficulty in purifying detectable amounts of protein. We therefore labeled endothelial cells with ${ }^{125} \mathrm{I}$, prepared NP40 extracts, mixed them with unlabeled platelet membranes, and applied the mixture to the B2.12 immunoaffinity column. Under these conditions, both GP IIb and GP IIIa were isolated from platelets (Fig. $5 \mathrm{~A}$ ), while an autoradiograph of the same gel revealed the presence of only a single protein from endothelial cells whose molecular weight was slightly higher than that of platelet GP IIIa (Fig. $5 \mathrm{~B}$ ). The decreased mobility on reduction characteristic of platelet GP IIIa was less apparent for the endothelial cell protein (Fig. 5 $B)$. The 40,000-mol-wt protein seen in Fig. $5 A$, lanes 2 and 3, co-migrated with actin.

Synthesis of GP IIIa-like protein by cultured endothelial cells. HAAE-IF in culture incorporated $\left[{ }^{35} S\right]$ methionine into several proteins (Fig. 6). After immunoaffinity chromatography of solubilized endothelial cells on a column of platelet GPIIIa-specific monoclonal B2.12, we obtained a radiolabeled

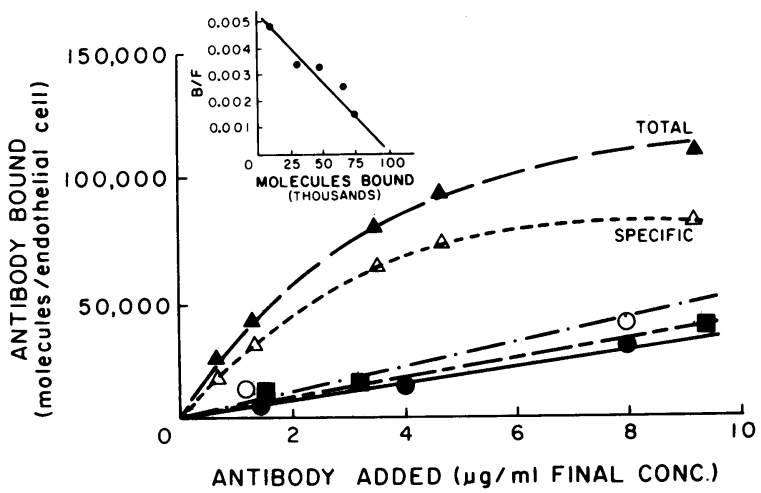

Figure 3. Binding of monoclonal antibodies to human umbilical vein endothelial cells. Endothelial cell suspensions were incubated with labeled monoclonal antibodies at $4^{\circ} \mathrm{C}$ for $10 \mathrm{~min} . \Delta,{ }^{125} \mathrm{I}-\mathrm{B} 2.12$ (antiplatelet GP IIIa); $\approx,{ }^{125} \mathrm{I}-\mathrm{B} 2.12$ in the presence of a 100 -fold excess of unlabeled B2.12; O, ${ }^{125}$ I-B59.2 (antiplatelet GP IIIa); •, ${ }^{125} \mathrm{I}-$ 66.7 (anti-T-cell); $\Delta$, specific binding of B2.12. Inset: Scatchard plot of specific binding of $\mathrm{B} 2.12$. 


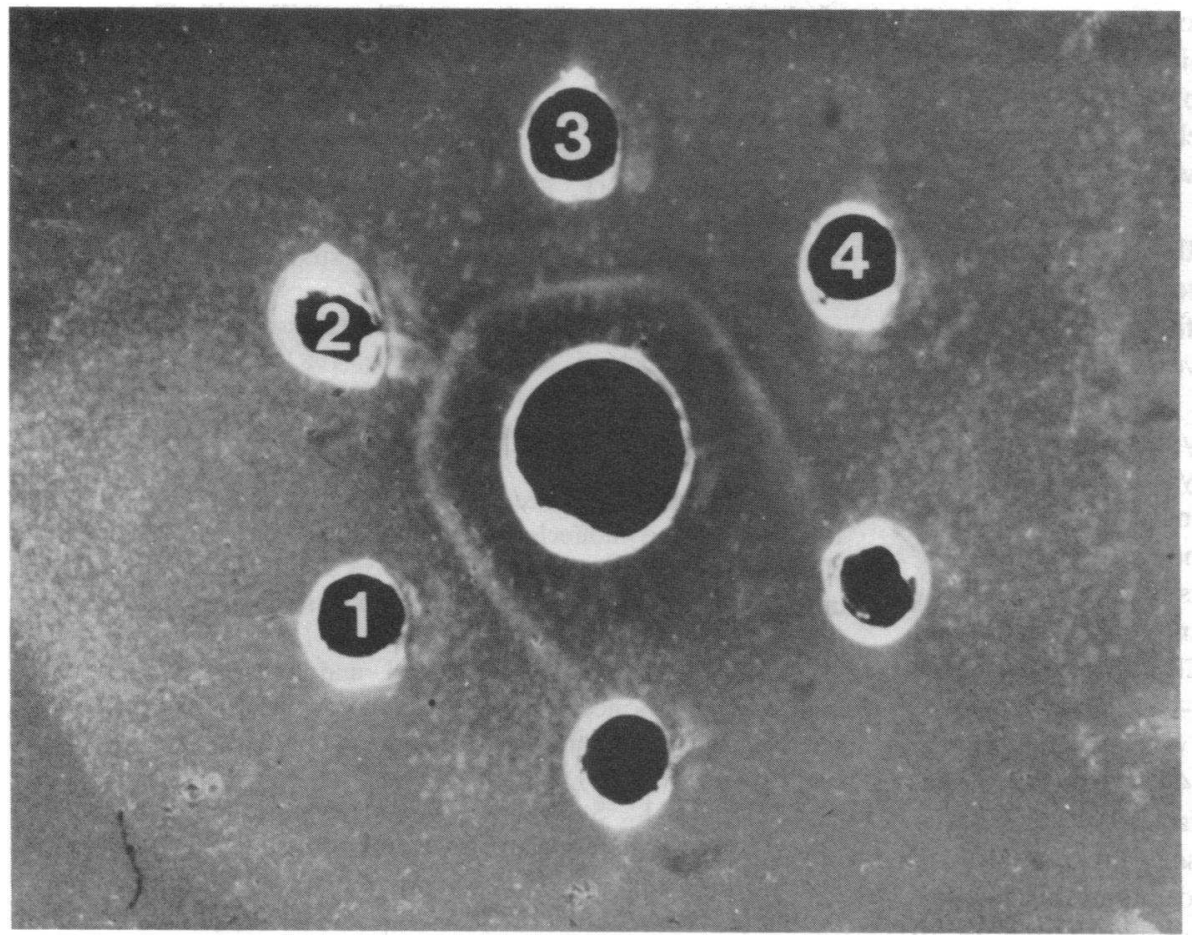

Figure 4. Reactivity of polyclonal antiGP-IIIa by double diffusion in agarose. Wells 1 and 4, platelets; well 2, endothelial cells; well 3, purified platelet GP IIla; center well, polyclonal antiserum to platelet GP IIIa. 95,000-mol-wt protein corresponding to GP IIIa, as well as several peptides of lower $(40-45,000)$ molecular weight. These may be proteolytic cleavage products of GP IIIa or may represent association of actin with GP IIIa, as has been reported for the platelet GP IIb-IIIa complex $(1,12,30)$. The radiolabeled 200,000 -mol-wt protein seen in the reduced gel is probably myosin.

\section{Discussion}

We have previously shown that monoclonal antibodies B2.12 and B59.2 are directed against the human platelet GP IIb-IIIa complex (30). In this paper we demonstrate that the immunoreactivity of both antibodies is directed more specifically against GP IIIa. Nevertheless, our immunoaffinity purification always resulted in the recovery of both GP IIb and GP IIIa from NP40-solubilized platelet membranes, even when purification was performed at neutral $\mathrm{pH}$ in the presence of EDTA.

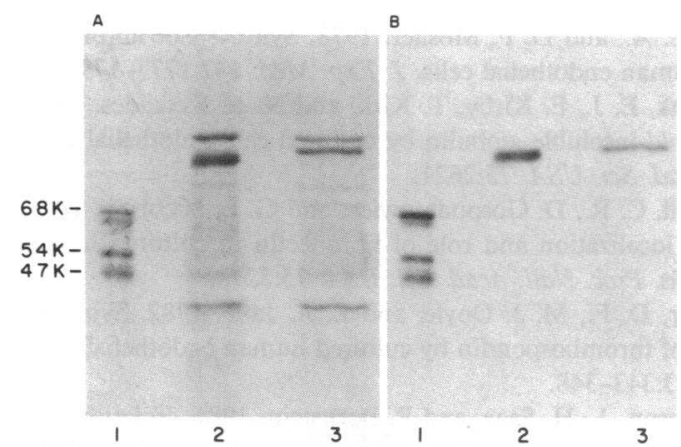

Figure 5. Immunoaffinity purification of a mixture of an unlabeled platelet extract and a ${ }^{125}$ I-labeled endothelial cell extract on B2.12 agarose. $(A)$ Coomassie blue stain; $(B)$ an autoradiogram of the same gel. Lane 1 , molecular weight standards; Lane 2, immunoaffinity column eluate, unreduced; Lane 3, immunoaffinity column eluate, reduced. $\mathrm{K}, \times 1,000 \mathrm{~mol}$ wt.
McEver et al. reported similar findings using a monoclonal antibody to GP IIb $(39,40)$. Such results probably arise because GP IIb and GP IIIa are present, even in unstimulated platelets, as a calcium-dependent heterodimer $(41,42)$, a complex that persists even after solubilization of the platelet membrane in detergents. Membrane solubilization in the presence of EDTA at neutral pH dissociates this complex to some extent; however, complete dissociation only occurs at pH 8.7 or higher (43).

Using monoclonal and polyclonal antibodies we have shown the presence in endothelial cell membranes of a protein related to platelet GP IIIa. This protein could be metabolically labeled by $\left[{ }^{35} \mathrm{~S}\right] \mathrm{methionine,} \mathrm{demonstrating} \mathrm{its} \mathrm{origin} \mathrm{from}$ endothelial cells. The endothelial cell and platelet proteins shared several epitopes, because they showed precipitin lines of identity against a polyclonal antiserum to platelet GP IIIa. Nevertheless they differed in at least one epitope, as demonstrated by the reactivity of endothelial cells to monoclonal B2.12, but not to monoclonal B59.2, both of which are specific for platelet GP IIIa. In addition, on the basis of Laemmli gels,

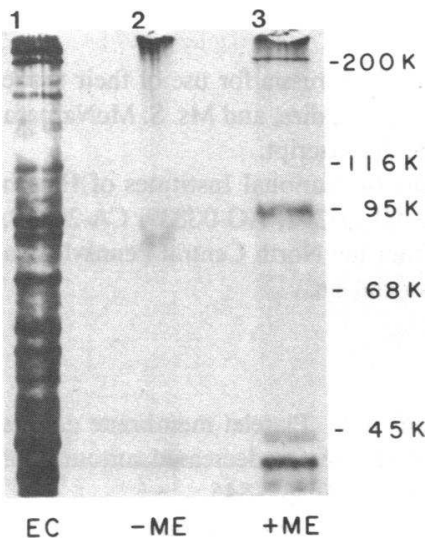

Figure 6. Immunoaffinity chromatography of ${ }^{35} \mathrm{~S}$-labeled endothelial cells on B2.12 agarose. Fluorogram of $\left[{ }^{35} S\right]$ methionine-labeled endothelial cells. Lane $1,{ }^{35}$ S-labeled Triton-solubilized endothelial cells; Lane 2, B2.12 immunoaffinity column eluate, reduced; Lane 3, B2.12 immunoaffinity column eluate, unreduced. $\mathrm{K}$, $\times 1,000 \mathrm{~mol} \mathrm{wt}$. 
the endothelial cell protein appeared to be about 2,000 D larger than platelet GP IIIa and showed little of the decreased mobility on reduction characteristic of platelet GP IIIa (Fig. 5). Further studies will be necessary to delineate the structural differences between this protein, which we shall term EC GP IIIa, and platelet GP IIIa.

Is EC GP IIIa complexed with a GP-IIb-like protein, as in platelets, or possibly with some other protein? Our preliminary data suggest not. Firstly, a monoclonal antibody against platelet GP IIb (gift of Dr. R. P. McEver, University of Texas, San Antonio) did not bind to endothelial cells. Secondly, no stoichiometric amounts of GP IIb or any other protein could be detected after GP IIIa immunoaffinity chromatography of endothelial cell extracts under conditions that, as we have already mentioned, always resulted in the appearance of GP IIb in the eluate from solubilized platelets.

GP-IIIa-related protein may be present in other cell types besides endothelial cells and platelets. Thus, Newman et al. (44) recently reported that one GP-IIIa-specific monoclonal antibody raised against platelets reacted with monocytes and neutrophils. In addition, Gogstad et al. (45), using polyclonal antibodies against the platelet GP IIb-IIIa complex, observed an immunoprecipitin reaction in crossed antigen-antibody electrophoresis of Triton X-100-solubilized monocytes. Neither B2.12 nor B59.2 bound to monocytes or neutrophils or to human aortic smooth muscle cells. However, our plateletspecific antibodies were initially selected on the basis of, among other properties, lack of reactivity toward other circulating blood cells. Thus, the possibility of GP-IIIa-related epitopes being common to platelets and monocytes or neutrophils cannot be completely excluded by our data.

The possible physiologic function of EC GP IIIa is not known. In stimulated platelets GP IIIa appears to be the site of fibrinogen binding, although this binding seems to require the presence of GP IIb as well (2). In addition, the GP IIb-IIIa complex was involved in Factor VIII antigen and fibronectin binding to thrombin-stimulated platelets, although the individual roles of the components of this complex have not been investigated. The presence of a GP IIIa-like protein in endothelial cells may endow these cells with some of the same binding properties. Preliminary experiments performed by us and others (46) suggest that fibrinogen may bind to endothelial cells. Studies are currently in progress in our laboratory to define more exactly the structure of EC GP IIIa and to investigate its possible role in the binding of fibrinogen, fibronectin, and Factor VIII to endothelial cells.

\section{Acknowledgments}

We thank Dr. G. Trinchieri and Dr. B. Perussia for use of their tissue culture facilities and the monoclonal antibodies, and Ms. S. McNamara and $F$. Hylan for preparation of the manuscript.

This work was supported in part by National Institutes of Health grants HL-27278, HL-09163, 5T32 HL-07371, AG-00839, CA-20833, and CA-32898, and a grant-in-aid from the North Central Pennsylvania Chapter of the American Heart Association.

\section{References}

1. Phillips, D. R., and P. P. Agin. 1977. Platelet membrane defects in Glanzmann's thrombasthenia: evidence for decreased amounts of two major glycoproteins. J. Clin. Invest. 60:535-545.

2. Nachman, R. L., and L. L. K. Leung. 1982. Complex formation of platelet membrane glycoproteins IIb and IIla with fibrinogen. $J$. Clin. Invest. 69:263-269.

3. Bennet, J. S., G. Vilaire, and D. B. Clines. 1982. Identification of the fibrinogen receptor on human platelets by photoaffinity labelling. J. Biol. Chem. 257:8049-8054.

4. Gogstad, G. O., F. Brosstad, M. B. Krutnes, I. Hagen, and N. O. Solum. 1982. Fibrinogen-binding properties of the human platelet glycoprotein IIb-IIla complex: a study using cross-radioimmunoelectrophoresis. Blood. 60:663-671.

5. DiMinno, G., P. Thiagarajan, B. Perussia, J. Martinez, S. S. Shapiro, G. Trinchieri, and S. Murphy. 1983. Exposure of platelet fibrinogen-binding sites by collagen, arachidonic acid and ADP: inhibition by a monoclonal antibody to glycoprotein IIb-IIIa complex. Blood. 61:140-148.

6. Coller, B. S., E. I. Peerschke, L. E. Scudder, and C. A. Sullivan. 1983. A murine monoclonal antibody that completely blocks the binding of fibrinogen to platelets produces a thrombasthenic-like state in normal platelets and binds to glycoproteins IIb and/or IIIa. J. Clin. Invest. 72:325-338.

7. Kornecki, E., G. P. Tuszynski, and S. Niewiarowski. 1982. Inhibition of fibrinogen receptor-mediated platelet aggregation by heterologous anti-human platelet membrane antibody. J. Biol. Chem. 258:9349-9356.

8. Howard, L., S. Shulman, S. Sadanandan, and S. Karpatkin. 1982. Crossed immunoelectrophoresis of human platelet membranes. J. Biol. Chem. 257:8331-8336.

9. Ruggeri, Z. M., R. Bader, and L. DeMarco. 1982. Glanzmann thrombasthenia: deficient binding of von Willebrand factor to thrombinstimulated platelets. Proc. Natl. Acad. Sci. USA. 79:6038-6041.

10. Ruggeri, Z. M., L. DeMarco, L. Gatti, R. Bader, and R. R. Montgomery. 1983. Platelets have more than one binding site for von Willebrand factor. J. Clin. Invest. 72:1-12.

11. Ginsberg, M. H., J. Forsyth, A. Lightsey, J. Chediak, and E. F. Plow. 1983. Reduced surface expression and binding of fibronectin by thrombin-stimulated thrombasthenic platelets. J. Clin. Invest. 71:619624.

12. Phillips, D. R., L. K. Jennings, and H. H. Edwards. 1980. Identification of membrane proteins mediating the interaction of human platelets. J. Cell Biol. 86:77-86.

13. Jamieson, G. A., T. Okumura, B. Fishback, M. M. Johnson, J. J. Egan, and H. J. Weiss. 1979. Platelet membrane glycoproteins in thrombasthenia, Bernard-Soulier Syndrome, and storage pool disease. J. Lab. Clin. Med. 93:652-660.

14. Jaffe, E. A., L. W. Hoyer, and R. L. Nachman. 1974. Synthesis of von Willebrand factor by cultured human endothelial cells. Proc. Natl. Acad. Sci. USA. 71:1906-1909.

15. Nachman, R. L., R. Levine, and E. A. Jaffe. 1977. Synthesis of factor VIII antigen by cultured guinea pig megakaryocytes. J. Clin. Invest. 60:914-921.

16. Jaffe, E. A., and D. F. Mosher. 1978. Synthesis of fibronectin by cultured human endothelial cells. J. Exp. Med. 147:1777-1791.

17. Macarak, E. J., E. Kirby, T. Kirk, and N. A. Kefalides. 1978. Synthesis of cold-insoluble globulin by cultured calf endothelial cells. Proc. Natl. Acad. Sci. USA. 75:2621.

18. Birdwell, C. R., D. Gospodarowicz, and G. L. Nicolson. 1978. Identification, localization and role of fibronectin in cultured bovine endothelial cells. Proc. Natl. Acad. Sci. USA. 75:3273.

19. Mosher, D. F., M. J. Doyle, and E. A. Jaffe. 1982. Synthesis and secretion of thrombospondin by cultured human endothelial cells. J. Cell. Biol. 93:343-348.

20. McPherson, J., H. Sage, and P. Bornstein. 1981. Isolation and characterization of a glycoprotein secreted by aortic endothelial cells in culture. J. Biol. Chem. 256:11330-11336.

21. DiCorleto, P. E., and D. F. Bowen-Pope. 1983. Cultured endothelial cells produce a platelet-derived growth factor-like protein. Proc. Natl. Acad. Sci. USA. 80:1919-1923.

22. Cerveny, T. J., D. N. Fass, and K. G. Mann. 1984. Coagulation factor V synthesis by cultured endothelium. Blood. 63:1467. 
23. Awbrey, B. J., J. C. Hoak, and W. G. Owen. 1979. Binding of human thrombin to cultured human endothelial cells. J. Biol. Chem. 254:4092-4095.

24. Ganguly, P. 1974. Binding of thrombin to human platelets. Nature (Lond.). 247:306-307.

25. Tollefsen, D. M., J. R. Feagler, and P. W. Majerus. 1974. The binding of thrombin to the surface of human platelets. J. Biol. Chem. 249:2646-2651.

26. Miletich, J. P., C. M. Jackson, and P. W. Majerus. 1978. Properties of the factor $\mathrm{Xa}$ binding site on human platelets. J. Biol. Chem. 253:6908-6916.

27. Rodgers, G. M., and M. A. Shuman. 1983. Prothrombin is activated on vascular endothelial cells by factor $\mathrm{Xa}$ and calcium. Proc. Natl. Acad. Sci. USA. 80:7001-7005.

28. Maciag, T., M. A. Hoover, M. B. Stemerman, and R. Weinstein. 1981. Serial propagation of human endothelial cells in vitro. J. Cell Biol. 91:420-426.

29. Kornecki, E., S. Niewiarowski, T. A. Morinelli, and M. Kloczewiak. 1981. Effect of chymotrypsin and adenosine diphosphate on the exposure of fibrinogen receptors on normal human and Glanzmann thrombasthenic platelets. J. Biol. Chem. 256:5696-5701.

30. Thiagarajan, P., B. Perussia, L. DeMarco, K. Wells, and G. Trinchieri. 1983. Membrane proteins on human megakaryocytes and platelets identified by monoclonal antibodies. Am. J. Hematol. 14: 255-269.

31. Nisonoff, A., F. C. Wissler, L. N. Lipman, and D. L. Woernley. 1960. Separation of univalent fragments from bivalent rabbit antibody molecule by reduction of disulfide bonds. Arch. Biochem. Biophys. 89: 230-244.

32. Hunter, W. M. 1973. Radioimmunoassay. In Immunologic Methods: Handbook of Experimental Immunology. Vol. 17. D. M. Weir, editor. Blackwell Scientific Publications, Oxford. 2.

33. Thornton, S. C., S. N. Mueller, and E. M. Levine. 1983. Human endothelial cells: use of heparin in cloning and long-term serial cultivation. Science (Wash. DC). 222:623-625.

34. Laemmli, U. K. 1970. Cleavage of structural protein during the assembly of the head bacteriophage T4. Nature (Lond.). 227:680681.

35. Gershoni, J. M., and G. E. Palade. 1982. Electrophoretic transfer of proteins from SDS polyacrylamide gels to a positively charged membrane filter. Anal. Biochem. 124:396-405.

36. Fraker, P. J., and J. C. Speck, Jr. 1978. Protein and cell membrane iodinations with a sparingly soluble chloroamide $1,3,4,6$ tetrachloro-3a,6a-diphenylglycoluril. Biochem. Biophys. Res. Commun. 80:849-857.

37. Haas, A. L., J. B. Warms, A. Hershko, and I. Rose. 1982. Ubiquitin activating enzyme. J. Biol. Chem. 257:2543-2548.

38. Parham, P. 1979. Purification of immunologically active HLA-A and -B antigens by a series of monoclonal antibody columns. J. Biol. Chem. 254:8709-8712.

39. McEver, R. P., N. L. Baenziger, and P. W. Majerus. 1980. Isolation and quantitation of the platelet membrane glycoprotein deficient in thrombasthenia using a monoclonal hybridoma antibody. J. Clin. Invest. 66:1311-1318.

40. McEver, R. P., E. M. Bennett, and M. N. Martin. 1983. Identification of two structurally and functionally distinct sites on human platelet membrane glycoprotein IIb-IIIa using monoclonal antibodies. J. Biol. Chem. 258:5269-5275.

41. Fujimura, K., and D. R. Phillips. 1983. Calciumcation regulation of glycoprotein Ilb-IIIa complex formation in platelet plasma membranes. J. Biol. Chem. 258:10247-10252.

42. Pidard, D., R. R. Montgomery, J. S. Bennett, and T. J. Kunicki. 1983. Interaction of AP-2, a monoclonal antibody specific for the human platelet glycoprotein IIb-IIIa complex, with intact platelets. J. Biol. Chem. 258:12582-12586.

43. Gogstad, G. O., I. Hagen, M. B. Krutnes, and N. O. Solum. 1982. Dissociation of the glycoprotein IIb-IIIa complex in isolated human platelet membranes. Biochim. Biophys. Acta. 689:21-30.

44. Newman, P. J., R. W. Allen, S. T. Roodman, T. J. Kunicki, and R. Kahn. 1983. A monoclonal antibody specific for human platelet membrane glycoprotein IIIa binds to monocytes and neutrophils. Blood. 62(Suppl.):263. (Abstr.)

45. Gogstad, G., O. Hetland, N. O. Solum, and H. Prydz. 1983. Monocytes and platelets share the glycoproteins IIb and IIIa that are absent from both cells in Glanzmann's thrombasthenia type I. Biochem. J. 214:331-337.

46. Dejana, E., M. V. Dauden, G. Balconi, A. Pietra, M. B. Donati, M. J. Larrieu, and G. Marguerie. 1983. Binding of fibrinogen to human endothelial cells. Thromb. Haemostasis. 50:401. (Abstr.) 